\title{
Assessment of the demand of critical materials for fuel cell micro CHP for households in Germany
}

\author{
Peñaherrera F.* and Pehlken A. \\ Carl von Ossietzky University of Oldenburg, Germany, Ammerländer Heerstraße 114, 26129 Oldenburg, Germany \\ Received: 26/02/2018, Accepted: 07/05/2018, Available online: 26/09/2018 \\ ${ }^{*}$ to whom all correspondence should be addressed: e-mail: fernando.andres.penaherrera.vaca@uni-oldenburg.de \\ https://doi.org/10.30955/gnj.002645
}

\begin{abstract}
Due to the pressing necessity of switching to alternative sources of energy, fuel cells (FC) for household applications have emerged as an alternative for decentralized energy supply. Despite the advancement on technological developments, concerns on the availability of critical raw materials required for the fabrication of these technologies may limit their implementation. This document analyses the demand of platinum for mass implementation of stationary fuel cells for household energy supply in Germany, through an analysis of the potential market, lifecycle of the product, material demands, and material flows. Different scenarios show that improving recycling rates and extending operation lifetime can help to mitigate the material needs even in the most demanding scenarios and reach material reuse targets. Methods and results can also be applied for other regions where FC have this potential applicability. Quality of data and its effects on the results need also to be further analyzed.
\end{abstract}

Keywords: MFA, platinum, stationary fuel cells.

\section{Introduction}

Concerns about fossil fuel stocks, supply security, and environmental impacts of emissions have stimulated governments and industry to explore the development of alternative sources of energy. This has led to the emergence of liberalized markets for energy and the growth of de-centralized generation and distribution systems (Brown et al., 2007).

Stationary Fuel Cells (SFC) applied for Combined Heat and Power (CHP) present a solution to reduce building energy use and emissions, using also existing fuel distribution infrastructure (Fuel Cell Today, 2017). First case studies have shown intensive energy savings of more than $50 \%$ (CALLUX, 2017), representing primary energy savings and reduction in transmission losses. Using natural gas as fuel, SFC can reduce $\mathrm{CO}_{2}$ emissions due to a more efficient conversion. Fuel Cell industry has gained traction in developed regions, such as Germany, Japan, and the USA (Amermann et al., 2017). Since FC technology is recent and is mainly applied to the mobility sector, there is nearly no assessment available for stationary fuel cells. Considering this trend, this paper assesses the future scenarios to estimate the demand of critical materials necessary for the supply of SFC to the market. This is performed using scenarios for development of the technology and evolution of its demand.

\section{State of the art of stationary fuel cell}

\subsection{General characteristics}

SFC provide power at a fixed location. They include small and large continuous power systems, backup or uninterruptible power supply (UPS), CHP, and combined cooling and power (Fuel Cell Today, 2017).

SFC size range from systems under $1 \mathrm{kWe}$ for household $\mathrm{CHP}$, larger units (several $\mathrm{kW}_{\mathrm{e}}$ ) for district heating or large buildings, and up to $\mathrm{MW}_{\mathrm{e}}$ for industrial applications and electricity supply. Conventional systems are already established for each application, such as gas engines, gas turbines, or combined cycle power plants (Pehnt, 2002). SFC can be classified by its application into two types: power-only (back-up and UPS) and CHP systems (Larminie and Dicks, 2003).

Two SFC types are mostly applied for household energy supply up to $10 \mathrm{~kW}_{\mathrm{e}}$ : Polymer Exchange Membrane Fuel Cell (PEMFC) and Solid Oxide Fuel Cell (SOFC). PEMFC operate with exhaust heat between 60 and $80^{\circ} \mathrm{C}$; and SOFC exhaust heat ranges from 650 to $1000{ }^{\circ} \mathrm{C}$ (ASUE, 2016). This study focuses on PEMFC, since they are also suited for ranges under $1 \mathrm{~kW}_{\mathrm{e}}$.

PEMFC have technological potential due to their similarity to the systems used in automotive applications, so their development is already advanced. PEMFC for residential energy supply operate in the range of $80^{\circ} \mathrm{C}$. PEMFC are relatively compact, and do not require insulation (Brown et al., 2007, p. 2176). They too run on natural gas, which has to be reformed into almost pure hydrogen before entering the system (Brown et al., 2007).

A platinum (Pt) catalyst is generally used for both the oxidation reaction at the anode and the reduction reaction at the cathode. $\mathrm{Pt}$ content is considered one of the main cost drivers of PEMFC (Wittstock et al., 2016). The use of Pt in SFC is higher than in mobile FC due to the 
requirement of continuous operation and of longer lifetimes, with Pt loadings in the ranges of $0,75 \mathrm{gPt}_{\mathrm{Pt}} \mathrm{kW}_{\mathrm{e}}^{-1}$, likely to reach 0,7 to $0,5 \mathrm{~g}_{\mathrm{pt}} \mathrm{kW}_{\mathrm{e}}^{-1}$ (Stahl et al., 2016).

Practical values for energy conversion efficiencies of SFC are $34,1 \%$ for electrical efficiency, $62,0 \%$ for thermal efficiency, and $96,1 \%$ total efficiency (CALLUX, 2017).

\subsection{Residential heating and electric energy supply}

CHP for household energy supply (micro-CHP) uses to the following technologies: Otto Motor, Stirling Motor, Steam Expansion, Organic Rankine Cycle (ORC), Micro-Gas turbine, and SFC (Erdmann, 2013).

Natural gas fueled CHP systems are to become one of the first major mass markets for SFC, as a replacement for boiler systems. The excess power is to be exported to the grid (ASUE, 2016). The power produced is preferentially self-consumed, with peak and backup power supplied from the grid. Micro-CHP systems range between 0,5 and $5 \mathrm{~kW}_{\mathrm{e}}$. SFC have a $30 \%$ better fuel utilization than central power plants (Stahl et al., 2016; ASUE, 2016; HFP, 2005).

Advantages include short start up times, high cycle stability and good partial load capacity, suiting them for intermittent and load variable operation. Disadvantages include a requirement of high purity of fuel, demanding a complex gas purification process (Jungbluth, 2007).

SFC two main applications suitable for market entry are: household or small commercial systems below $50 \mathrm{~kW}_{\mathrm{e}}$, with focus on micro-CHP below $5 \mathrm{~kW}_{\mathrm{e}}$; and industrial applications with ranges of 200 to $500 \mathrm{~kW}_{\mathrm{e}}$ (HFP, 2005).

\section{Methodology}

This analysis focuses on the recovery of critical materials (CM) from SFC, because of the special challenges in the recovery of valuable and precious metals present in relative small quantities in these devices (Hagelüken et al., 2016). The recovery of secondary metals has a lower energy intensity than mining in most cases, as the metal concentration in many products is higher than in ores, such as in the case of precious and rare metals in electronic products (Hagelüken et al., 2016). CM identified in a SFC for recycling are $\mathrm{Pt}$, and $\mathrm{Co}$ as a possible substitution material (WGCRM, 2014).

\subsection{Stages of the life cycle of a stationary PEMFC}

To analyze the flow of Pt during the lifecycle of the PEMFC, different stages are considered in this paper: Material acquisition, Production, Operation, and End of Life (EoL). Literature values of percentages of material loss or recovery for each stage are presented.

\subsubsection{PEMFC production and material losses}

$15 \%$ of the catalyst material is lost in the electrode coating process. Process losses in the region of $5 \%$ to $20 \%$ can be expected for automated, industrial-scale coating of membrane rolls, with catalyst ink scrap rate of $10 \%$. Fraunhofer IPA, as quoted by BUBW (2015), suggests typical overspray losses as high as $90 \%$ (Wittstock et al., 2016). Technological developments can reduce the material losses during the fabrication of the Membrane Electrode Assembly (MEA).
Additional losses can occur during the fabrication process of the FC stack, as a fraction of the manufactured PEMFC units may not comply with quality control procedures. Assuming a high value of confidence for the manufacturing process, the discarded products are lower than 2\% (Shokri et al., 2015; Matathil et al., 2012), with target values of $0,1 \%$ (Matathil et al., 2012).

\subsubsection{Fuel cell operation and life time}

PEMFC MEA require periodic replacement because of gradual irreversible degradation in performance, so the demand of CRM for replacement, additional to demand for new systems, requires consideration. Durability is a key issue for the implementation of fuel cells (Dodds et al., 2015). Limited information on PEMFC system reliability is available (Fecarotti et al., 2016).

The FC stack is considered to fail whenever it is not able to provide the required power output (Fecarotti et al., 2016). The required lifetime of SFC MEA is up to $40000 \mathrm{~h}$ to be considered economically feasible (Knights et al., 2004; Belvedere et al., 2013; Fecarotti et al., 2016).

A probabilistic model is used to estimate the operation lifetime of a fuel cell, to calculate the required number of units to be produced for replacement, and to estimate the number of units that come out of service for EoL processing. Fecarotti et al. (2016) propose a Weibull distribution model and provide results on the lifetime of a PEMFC based on modelling the failure of the different components. A maximum average lifetime of $14246 \mathrm{~h}$ is estimated, around 3 years of operation (Figure 1).

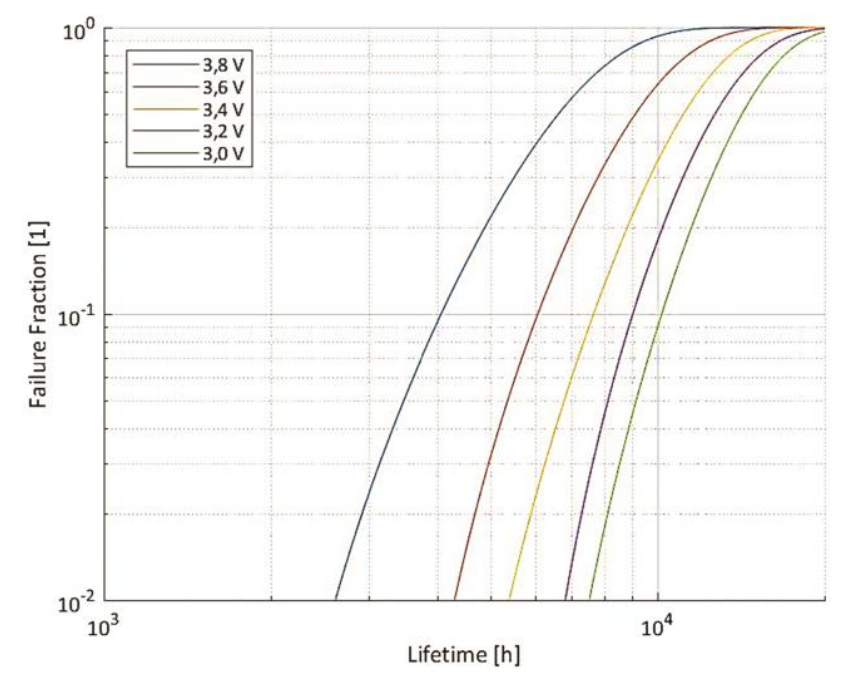

Figure 1. Failure fractions predicted Adapted from Fecarotti et al. (2016)

The lifetime of the stack for future configurations is required to be at least 6 years to be commercially applicable (DLR, 2004), assuming $5000 \mathrm{~h}$ per year for intermittent residential operation. The leading Japanese residential systems are now expected to operate for 60 to $80000 \mathrm{~h}$ for PEMFC (Dodds et al., 2015). The degradation rate of the stack can reach up to about $1 \%$ per year (CALLUX, 2017). This would allow an operation of 10a, with a requirement to overhaul the fuel cell stack after 
5a (Dodds et al., 2015). Grot, Grot (2007) indicate that no significant amount of $\mathrm{Pt}$ is lost in the exhaust of a fuel cell system over its life. (Grot and Grot, 2007). Kromer et al. (2009) indicate use phase material losses of 0,35\% per year, and Wittstock et al. (2016) use a value of 0,68\% per year.

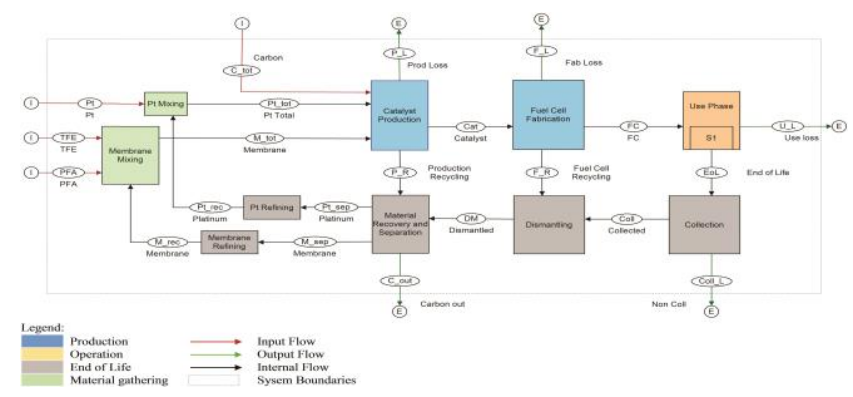

Figure 2. MFA model for SFC

\subsubsection{End of life}

To make PEMFC technology economically and ecologically feasible, its commercialization requires improvements on industrial production processes for the MEA, and also rational processes for recovering the precious metals (Köhler et al., 2006).

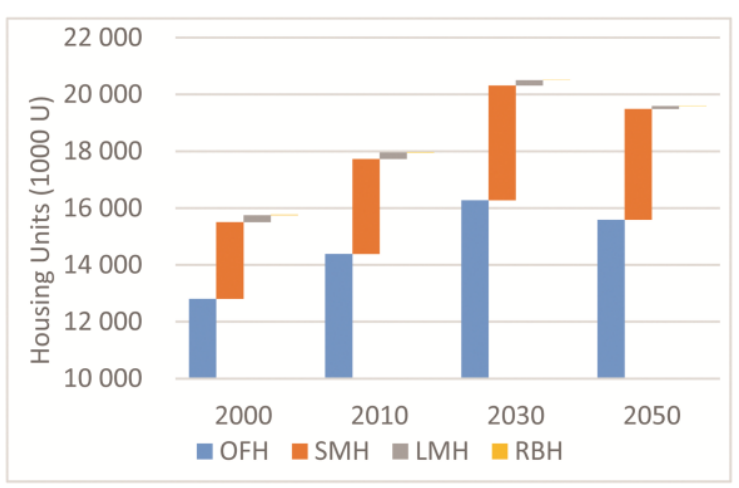

Figure 3. Number of housing units and prognosis up to 2050 Modified from Jungbluth (2007)

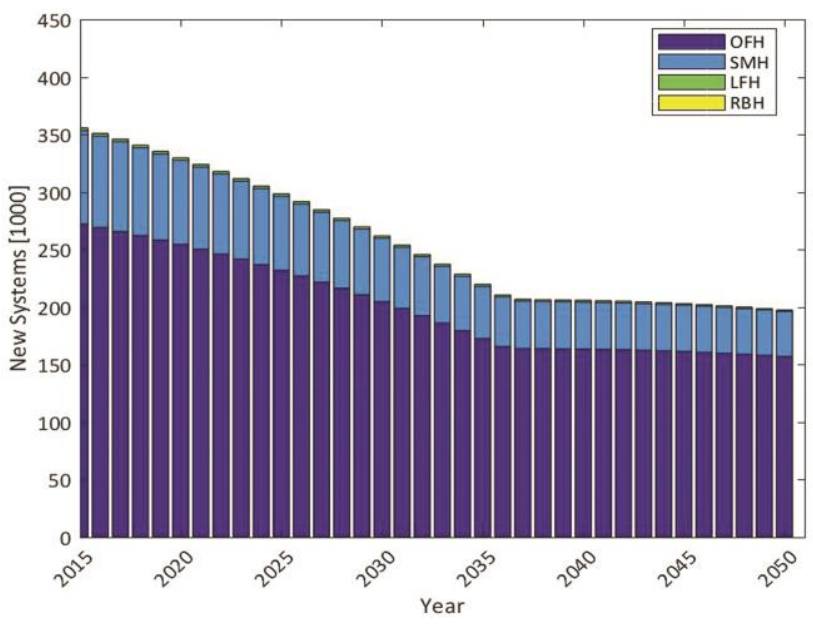

Reuse of SFC MEA at the end of its lifetime is not feasible, as failure is often caused by MEA degradation. Reparation of any component could risk irrevocably damaging the others (Simons and Bauer, 2015).

SFC recycling is aimed at recovering the valuable CRM (Wittstock et al., 2016), which would further reduce the material demand for stacks (Thijssen, 2011). Recycling provides a mechanism for reintroducing valuable materials back into the economy, while lowering environmental impacts and the energy intensity of material supply (Hagelüken et al., 2016). CRM are spread within the product, so partial loss is inevitable for highly complex products, impending $100 \%$ recovery (Hagelüken et al., 2016). The biggest challenges to achieve high rates of recycling are the insufficient collection of consumer goods and inefficient handling within the recycling chain (Hagelüken, 2012).

Waste of Electric and Electronic Equipment (WEEE) have CRM recycling rates below $15 \%$. Rates could reach over $95 \%$ if all waste materials were efficiently transferred to state-of-the-art metallurgical refineries (Hagelüken et al., 2016). For an effective recovery of material, all the preceding stages in the recycling chain would need to collect the respective material handled with 99\% efficiency to achieve an overall recycling rate of $95 \%$ (Wittstock et al., 2016). An overall global recycling quota for Pt of $70 \%$ (currently about $45 \%$ ) should be the minimum target for 2020 (UMICORE, 2005), and 80\% for 2030 (Buchert et al., 2011; UNEP, 2009).

Similar to a recycling chain for automotive catalysts, the first step to recover CRM from SFC is to collect and then dismantle them (Saternus et al., 2014). A release of platinum in a significant amount from the FC into the environment in this step is highly unlikely (Stahl et al., 2016).

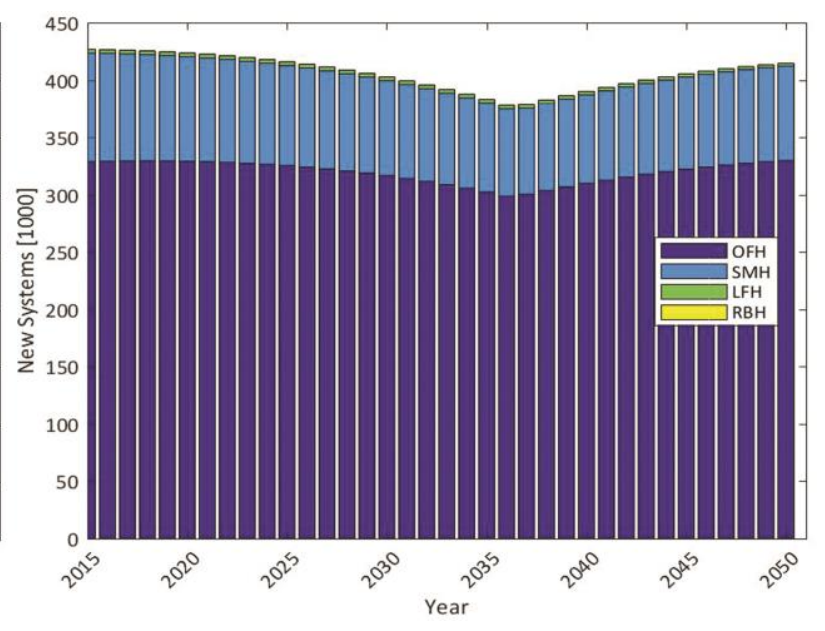

Figure 4. Annual requirement of new heating systems Left: Reference Scenario. Right: Ecological Scenario 
Recycling rates differ highly between sectors, with industrial applications achieving recovery rates of 80 to $90 \%$ over the whole lifecycle compared to only 5 to $60 \%$ for consumer goods (Hagelüken, 2012). For consumer products, especially products with a long lifetime, such as automotive catalysts, only about 50 to $60 \%$ of $\mathrm{Pt}$ is recycled (Zepf and Simmons, 2014). Pt recovery rates of $98 \%$ and above can be achieved. Precious metal losses during dismantling phase account to $3,4 \%$ of the original load (Wegner, 2012).

\subsection{Material flow analysis (MFA) for SFC}

This section analyses the demand of CRM for their use in SFC household applications for the German market. A model is constructed to analyze the flow of CRM during the different stages the lifecycle of SFC. Market scenarios for demand of SFC CHP residential units are analyzed, considering different acceptance of the technology. Fractions for losses and recovery in the different stages are introduced in the model.

\subsubsection{MFA model for Pt in SFC}

A MFA model is constructed to analyze the demand of CRM based on the stages described in Section 3.1 (Figure 2). The lifecycle is divided in different stages: Raw Material Acquisition, Production, Use, and EoL. For each process, Transfer Coefficients (TC) are defined as fractions that are either lost out of the system or are reincorporated in the EoL recycling process. This analysis focuses on the German market until 2050, linked to the European targets for reduction of emissions.

\subsubsection{Demand forecast of FC CHP in Germany}

This section analyses the housing market in Germany, presenting estimation for the number of residential units to be constructed, replaced or renovated, as these units are a potential market for new SFC CHP units. Replacement of conventional operating systems for SFC CHP units is not deemed as economically feasible, hence only new units are considered (Jungbluth, 2007).

Table 1. Optimal installation size of FC CHP units Data from Jungbluth (2007)

\begin{tabular}{ccccc}
\hline \multirow{2}{*}{$\begin{array}{c}\text { Buildin } \\
\text { g type }\end{array}$} & \multicolumn{2}{c}{$\begin{array}{c}\text { Private user/ } \\
\text { reference scenario }\end{array}$} & \multicolumn{2}{c}{$\begin{array}{c}\text { Contracting model/ } \\
\text { ecological scenario }\end{array}$} \\
\cline { 2 - 5 } & $\begin{array}{c}\text { Feasible } \\
\text { size }\end{array}$ & $\begin{array}{c}\text { Operation } \\
\text { hours }\end{array}$ & $\begin{array}{c}\text { Feasible } \\
\text { size }\end{array}$ & $\begin{array}{c}\text { Operatio } \\
\text { n hours }\end{array}$ \\
\cline { 2 - 5 }$\left[\begin{array}{c}{\left[W_{\mathrm{e}}\right]} \\
{[\mathbf{h}]}\end{array}\right.$ & {$\left[\mathbf{k W}_{\mathrm{e}}\right]$} & {$[\mathrm{h}]$} \\
\hline OFH & 0,5 & 5700 & 1,8 & 4400 \\
\hline SFH & 2,0 & 4800 & 6,0 & 5500 \\
\hline LFH & 5,0 & 6500 & 11,0 & 5200 \\
\hline
\end{tabular}

One family houses (OFH), small multi-family houses $(\mathrm{SMH})$, large multi-family houses $(\mathrm{LMH})$, and residential buildings ( $\mathrm{RBH}$ ) are the principal potential markets for SFC (Figure 3, Jungbluth, 2007). More than 17 million of heating devices are used in residences in Germany through the burning of gas and oil (Töpler and Lehmann, 2014). More than three quarters are heated by central heating. About 15,1 million are 1 or 2 family houses; 2,3 million are multi-family houses (Erdmann, 2013).
Natural gas is used in $47,8 \%$ of the OFH and $\mathrm{SMH}$, and in $47,7 \%$ of the residential buildings (BDEW, 2015). Micro CHP units with 1 to $2 \mathrm{~kW}_{\mathrm{e}}$ and 3 to $10 \mathrm{~kW}_{\text {th }}$ provide this energy (Erdmann, 2013). A residence with 4 inhabitants demands an average of $5 \mathrm{MWh}_{\mathrm{e}} \mathrm{a}^{-1}$, representing $570 \mathrm{~W}$ of average power. Most of the household applications are estimated to be smaller than 1 kW (Töpler and Lehmann, 2014, p. 141).

The market for new CHP units estimated is related to the number of new buildings, buildings required as replacement for demolished units, and renovated buildings that upgrade the insolation and heating systems. Yearly rates are used to estimate these units. Jungbluth (2007) presents two different scenarios for this development: Reference and Ecological. Reference Scenario assumes a slow acceptance of the technology, a lower market demand, and a required of smaller units, when compared to the Ecological scenario, where the acceptance of technology grows faster, and a higher demand is present in the market, accompanied of a request of units of higher nominal power.

In the Reference scenario, the rates for demolition and renovation are fixed at $0,5 \%$ per year. In the Ecological scenario, the rates are continuously growing and are assumed so that by 2050 all buildings existing before 1998 are either replaced or renovated. The share of SFC within the micro-CHP sector over time is assumed to achieve $90 \%$ by 2050 (Krewitt et al., 2006). The application of these values results in the number of buildings requiring $a$ new heating system (Figure 4).

Considering the fraction of residential buildings that use natural gas, $44,7 \%$, the potential market for SFC CHP systems is calculated using forecasted rates for acceptance of SFC technology (Figure 5). Increasing entry rates of SFC into the market are assumed: fast and slow introduction of technology for the reference and ecological scenario, respectively. The number of new or renovated buildings demanding FC CHP units for each residence type is calculated applying these fractions (Figure 6).

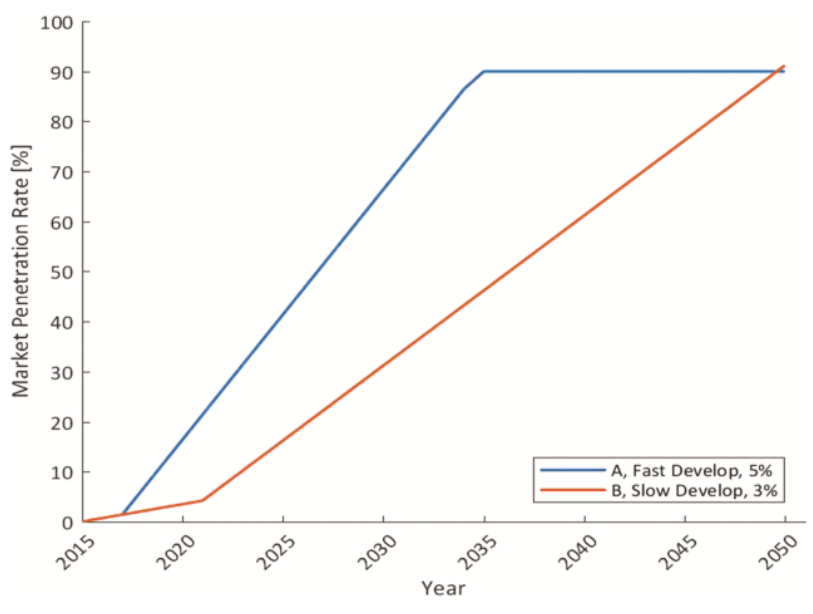

Figure 5. SFC CHP market entry rates 

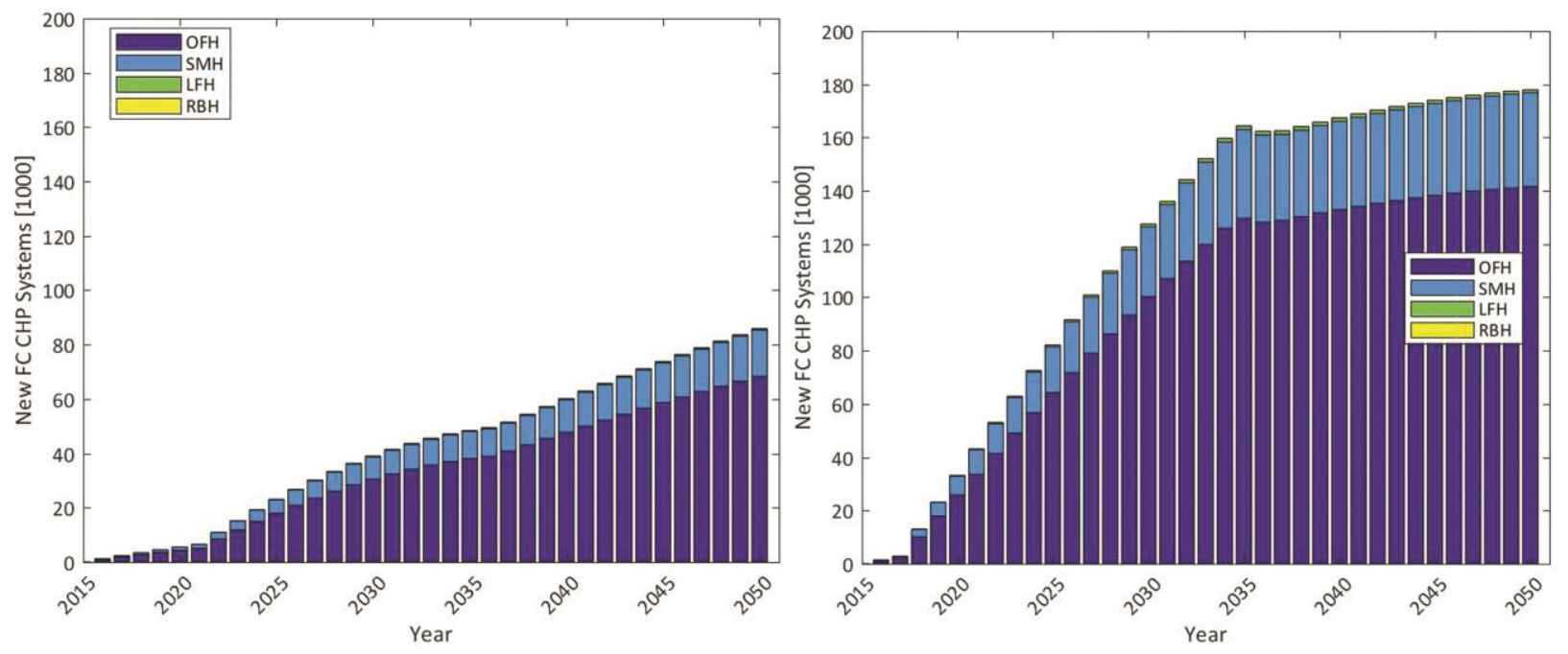

Figure 6. SFC CHP demand for residential heating Left: Reference Scenario. Right: Ecological Scenario
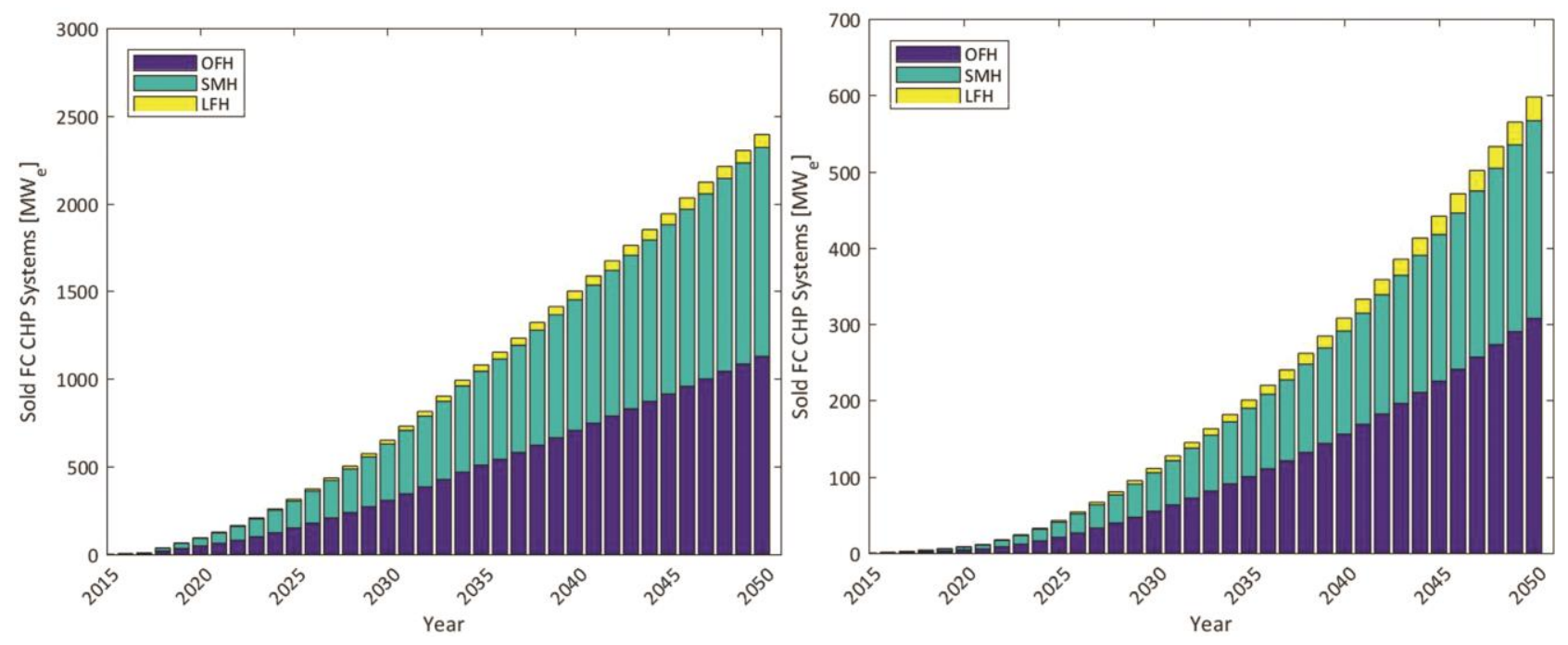

Figure 7. SFC CHP units placed in the market, in $\mathrm{kW}_{\mathrm{e}}$. Left: Reference Scenario. Right: Ecological Scenario

Jungbluth (2007) estimated the optimal size of a SFC CHP system to be economically feasible. Two business models for use of the SFC CHP units are considered: private User and contracting model (Table 1).

The values of operation hours and the models for failure rate are used to calculate the number of SFC CHP units that need to be placed into the market, as units for new systems or as replacement for existing systems. The total amount of SFC can be expressed in $\mathrm{kW}_{\mathrm{e}}$ of peak power placed in the market, which is calculated by multiplying the number of units and the individual optimal power (Figure 7).

\subsubsection{MFA model for fuel cells}

The Pt demand can be calculated using the values in Figure 7 and the values of Pt load $\left(\mathrm{kg}_{\mathrm{Pt}} \mathrm{kW}_{\mathrm{e}}^{-1}\right)$ to estimate the demand of CRM for SFC CHP units. The Pt load is expected to continuously decrease as the technology develops, with target values of $0,5 \mathrm{~kg}_{\mathrm{Pt}} \mathrm{kW}_{\mathrm{e}}^{-1}$ to be reached by 2025 . Using the yearly operation hours (Table 1) and the expected life time for each model of SFC CHP system, the number of units coming out of service and the Pt content in these units is calculated.

Table 2. Transfer coefficients used for MFA

\begin{tabular}{cccc}
\hline \multirow{2}{*}{ Value } & \multirow{2}{*}{ Ref. Scen. } & \multicolumn{2}{c}{ Ecol Scen } \\
\cline { 3 - 4 } & & $\mathbf{2 0 1 7}$ & $\mathbf{2 0 5 0}$ \\
\hline MEA production loss & $40 \%$ & $15 \%$ & $5 \%$ \\
\hline FC production loss & $5 \%$ & $2 \%$ & $0,1 \%$ \\
\hline Recollection rate & $15 \%$ & $60 \%$ & $95 \%$ \\
\hline Dismantling loss & $3,4 \%$ & $3,4 \%$ & $1 \%$ \\
\hline Separation loss & $10 \%$ & $5 \%$ & $1 \%$ \\
\hline
\end{tabular}



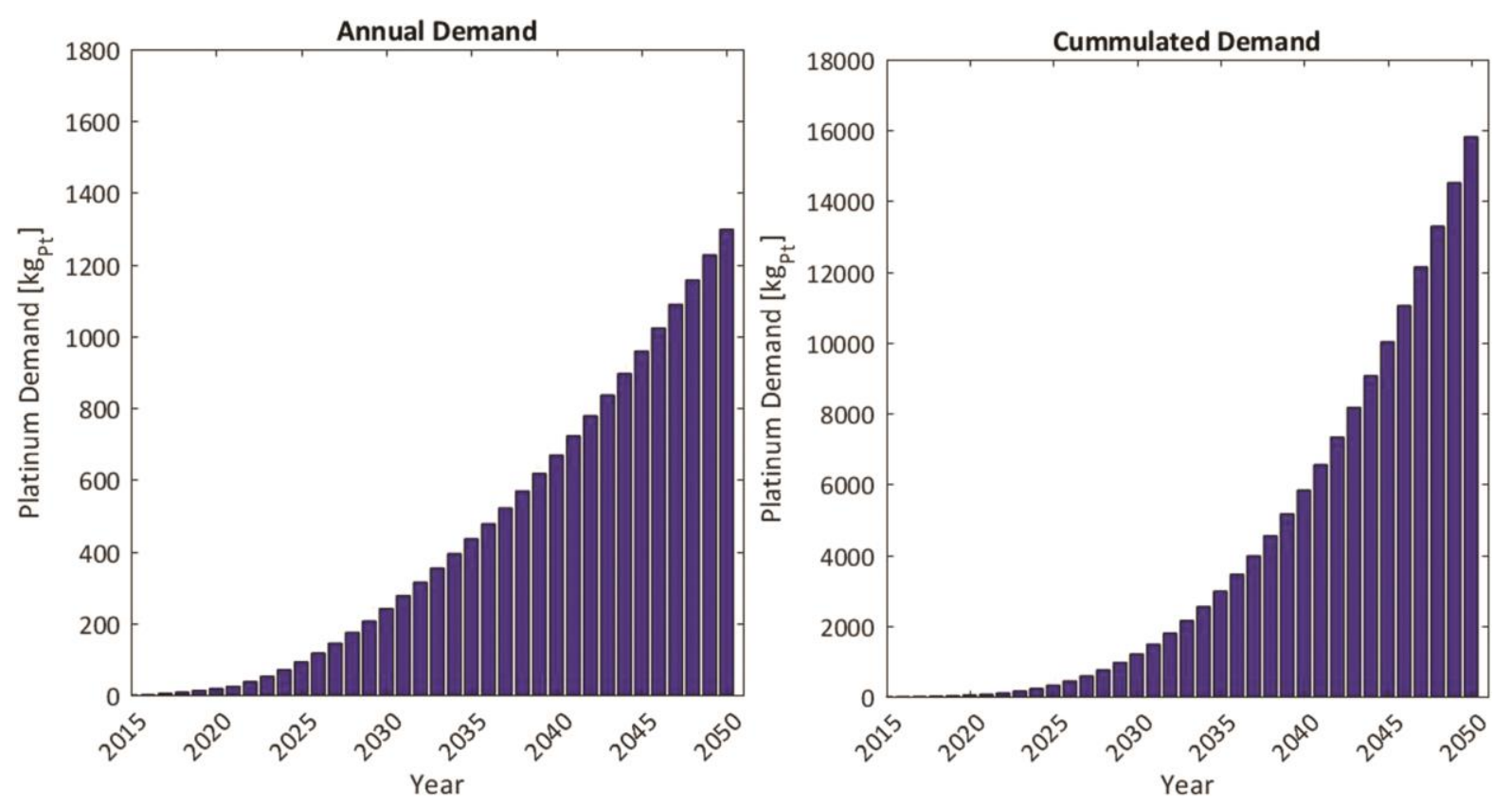

Figure 8. Pt demand for the Reference scenario
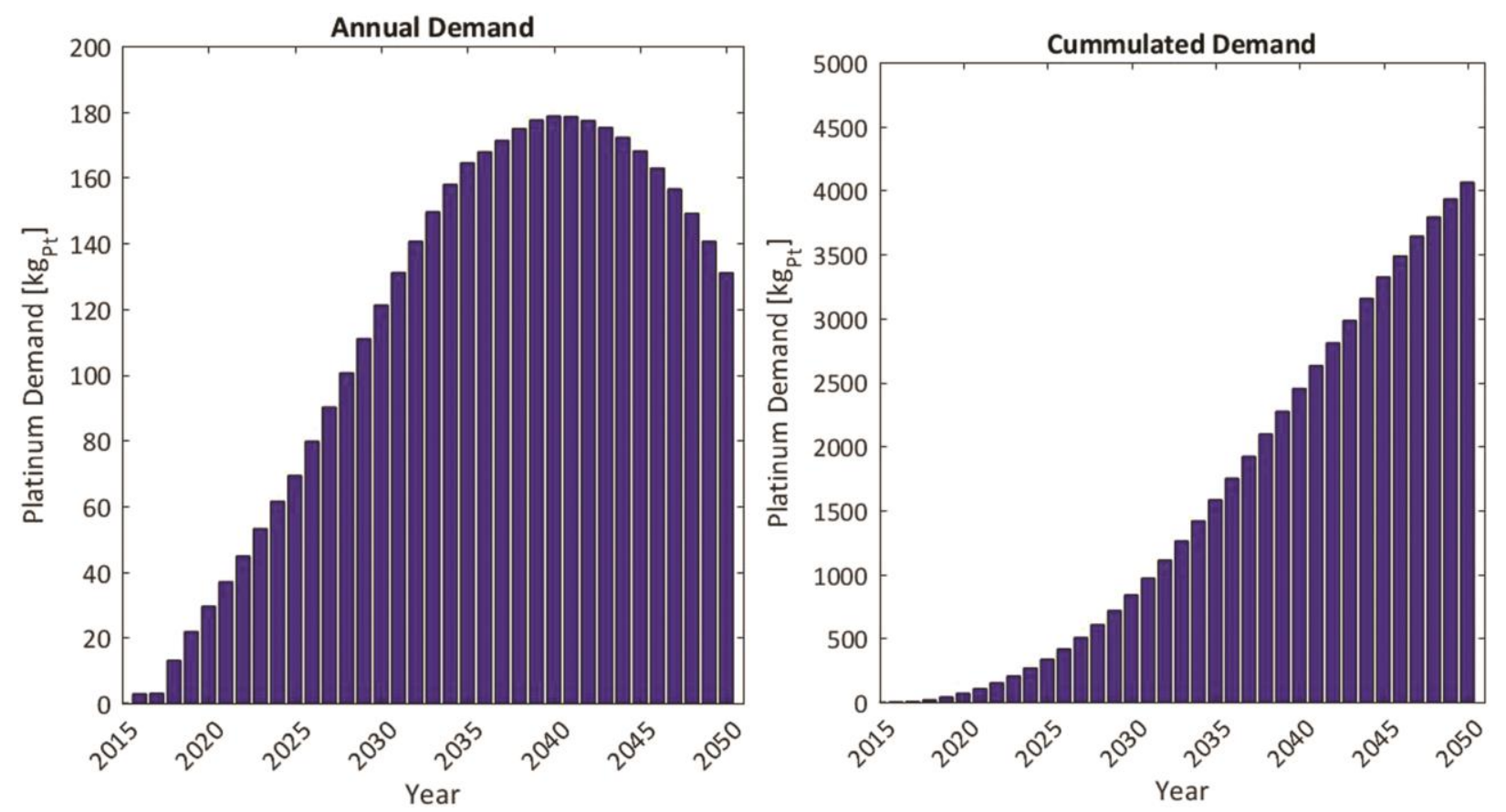

Figure 9. Pt demand for the Ecological scenario

The values of Pt content in units coming in and out of service phase is used in a MFA model to calculate the required input of raw Pt. The model considers losses in different production stages and different recovery rates for EoL stages. A model is built in Simulink, which allows further analysis of dynamic scenarios and uncertainties. The Reference scenario assumes values for the TC on the low spectrum of those found on the literature review, and assumes these values remain constant and without improvement. The Ecological scenario assumes higher values, a continuous improvement in recycling and collection, and a reduction in production and fabrication losses (Table 2). Results on cumulated platinum demand for both scenarios are calculated (Figures 8 and 9).

The CRM reuse rate, defined as the amount of $\mathrm{Pt}$ recovered coming from recycling processes divided by the required amount for manufacturing, reaches values close to $90 \%$ only after continuous improvements in all the stages of the lifecycle (Figure 10). 


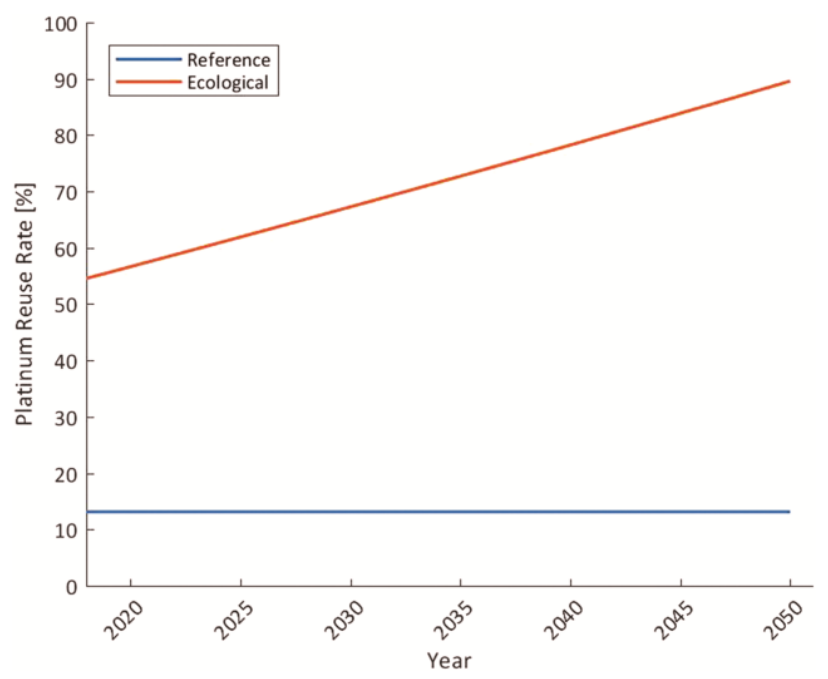

Figure 10. Material reuse rate for different scenarios

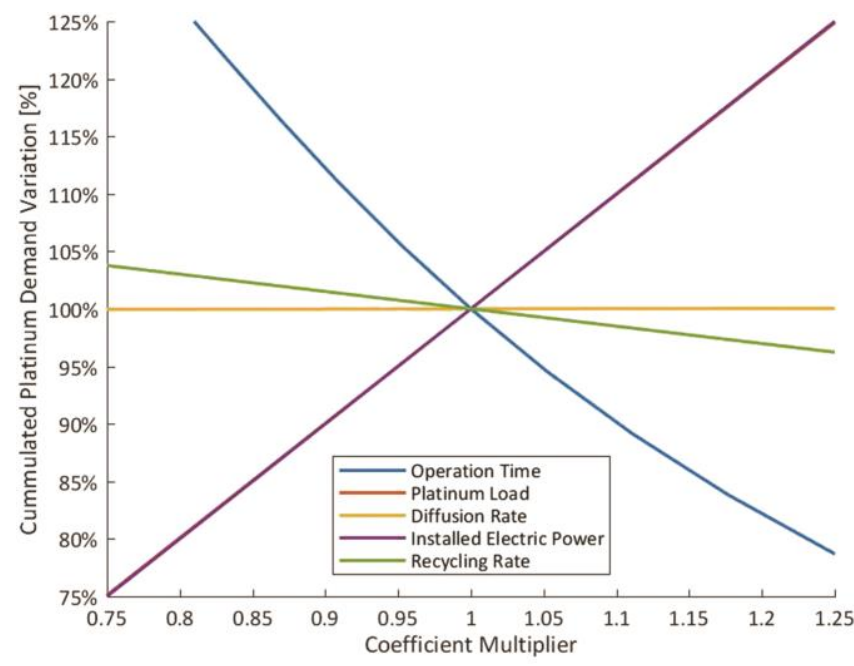

\subsubsection{Sensitivity analysis}

The different values for the input of the model parameters affect the results on cumulated Pt demand. The influence of values of $\mathrm{Pt}$ content, lifetime (or operation hours), diffusion rate, Pt load, and installed power have different effect on the results. The input values in the MFA model are altered to calculate these changes (Figure 11).

\section{Results analysis and discussion}

The MFA model for Pt in SFC allows distinction in four phases: material acquisition, SFC production, operation, and EoL. This model allows the differentiation of different stages and the application of TC from similar products or from research values (Figure 2).

Figure 11. Sensitivity analysis for different factors

Left: Reference scenario. Right: Ecological scenario

The estimation of the number of housing units and its disaggregation in categories allows extrapolation of future demand (Figure 3). A decline in the required number of building units after 2030 produces a stagnation at around 200 thousand units on the requirement new heating systems in the reference scenario, and a constant requirement of about 400 thousand units in the ecological scenario (Figure 4). Due to differences in the expected market entry rate of SFC in the residential heating market, the annual demand of SFC for CHP grows continuously to 80 thousand units in the reference scenario and reaches 180 thousand units in the ecological scenario (Figure 6). The difference in the optimal size of the SFC CHP systems, operation hours, and lifetime, result in a requirement of $600 \mathrm{MW}_{\mathrm{e}}$ of SFC placed in the market for the reference scenario, and around $2500 \mathrm{MW}_{\mathrm{e}}$ for the ecological scenario, including units required for replacement of degraded stacks and out of service units (Figure 7).
The application of these market demands and different values of TC for the material flows indicate that for 2050, SFC CHP manufacturing annual demand is $1200 \mathrm{~kg}_{\mathrm{Pt}}$ in the reference scenario and $130 \mathrm{~kg}_{\mathrm{Pt}}$ in the ecological scenario. The last scenario reaches a peak in material demand close to $180 \mathrm{~kg}_{\mathrm{pt}}$, with further reduction of the demand. This is explained by expected improvements in collection and recycling rates, even though this scenario presents a higher demand of units. Cumulated Pt demand reaches 16 ton $_{\mathrm{Pt}}$ in the reference scenario and around 4 ton $_{\mathrm{Pt}}$ in the ecological scenario (Figures 8 and 9). Despite the requirement of around 4 times additional power for the ecological scenario in comparison to the reference scenario, the material demand of the ecological scenario is 4 times lower than of the reference scenario. This is also indicated in the material reuse rate, where rates of $90 \%$ are achieved only after continuous improvement on manufacturing procedures and EoL treatment in the ecological scenario (Figure 10). 
Reduction in operation time means also an extension in lifetime, which lowers the number of units required for replacement, and thus the total demand of $\mathrm{Pt}$ in both scenarios. Recycling is the most important factor in the ecological scenario, and progressive increments in recycling rates can greatly reduce the material demand. This is unlike the reference scenario, where the losses during the production phase are more important. The installed power capacity and Pt load of the units increase the demand proportionally. The diffusion rate has a minimal impact in the total demand, since the diffusion rate is lower than the other factors such as recycling rate or production losses (Figure 11).

\section{Conclusion and outlook}

SFC present advantages for energy supply, due to their higher efficiency and lower emissions. The results of models indicate a growing market for FC, with close to 800 thousand units required for 2050 under the highest demand scenario. Although the number of households with SFC CHP systems differ for different scenarios, an extended operation lifetime for the ecological scenario reduces the demand in all cases.

For their implementation to be feasible, the supply of CRM for fabrication of the CHP units needs to be taken in consideration. Most of the units required are smaller than $2 \mathrm{~kW}_{\mathrm{el}}$ which makes PEMFC the most feasible technology to be implemented. It is estimated that under all scenarios fuel cells will achieve a market share of $90 \%$ of CHP plants for household application systems by 2050 . Current technological limitations for their implementation are the amount of material loss during their production, the content of PGM (Platinum Group Metals) in the catalyst, and their short operation lifetime. The reduction of manufacturing losses and a proper implementation of recycling chains for the CHP units can help greatly to reduce the demand of material and could reach values in the range of $90 \%$ of recycled material, surpassing the expected reuse quotas. A total of 16 ton $_{\mathrm{Pt}}$ for the Reference scenario and 4 ton $_{\mathrm{Pt}}$ in the Ecological scenario are estimated to be required for manufacturing PEMFC, this difference owing to better manufacturing and EoL procedures for the latter scenario. However, the impact of Pt consumption, in the order of 4 to 16 tons, on the overall resource availability is minimal, with platinum resources in the order of 100000 ton $_{\mathrm{pt}}$. Hence the recovery of CRM from SFC has as benefit reducing production costs by recovering $\mathrm{Pt}$, the main cost driver in the SFC MEA.

The data quality has a significant impact on the uncertainty of the results. Further analysis requires the consideration of data quality and development probabilistic models to assess the results uncertainties. Data of optimal power is taken from existing models, and more recent data on household energy demand and optimal size of a SFC is needed. This paper was based on future scenarios with a positive market penetration of SFC in households. So far, the costs of FC heating systems were neglected in this paper but play a big role for surviving in the market without subsidies. The influence of
Pt demand of other markets, such as USA, EU or Asia, and possible application of other technologies such as SOFC is also to be assessed using similar methodologies.

\section{Acknowledgements}

Part of this study was funded through the Project Netonia, funded by the BMBF, Germany with the funding 01DS16011B and Cascade Use with 01LN1310A.

\section{References}

Ammmermann H., Hoff P., Atanasiu M., Ayllor J., Kaufmmann M. and Tisler O. (2017), Advancing Europe's Energy Sysyems. Stationary Fuel Cells in Distributed Generation. A Study for the Fuel Cells and Hydrogen Joint Undertaking, Edited by Publications Office of the European Union, Luxemburg, Luxemburg. Available online at http://www.fch.europa.eu/ publications/advancing-europes-energy-systems-stationaryfuel-cells-distributed-generation, checked on 11/27/2017.

ASUE (2016), Brennstoffzellen für die Hausenergieversorgung. Funktionsweise, Entwicklung und Marktübersicht. Berlin, Germany: ASUE e.V. Available online at http://www.asue.de/ sites/default/files/asue/themen/brennstoffzellen/2016/bros chueren/05_03_16_asue_brennstoffzellen_hausenergievers orgung.pdf, checked on 11/27/2017.

BDEW (2015), Wie heizt Deutschland? BDEW-Studie zum Heizungsmarkt. BDEW Bundesverband der Energie- und Wasserwirtschaft e.V. Berlin, Germany. Available online at https://www.bdew.de/internet.nsf/id/C44E72D1F65D174EC 1257DAC00319783/\$file/141212\%20BDEW\%20Studie\%20Wi e\%20heizt\%20Deutschland\%20Anhang.pdf, checked on $11 / 27 / 2017$.

Belvedere B., Bianchi M., Borghetti A., Pascale A.de., Paolone M. and Vecci R. (2013), Experimental analysis of a PEM fuel cell performance at variable load with anodic exhaust management optimization. International Journal of Hydrogen Energy, 38(1), 385-393. DOI: 10.1016/ j.ijhydene.2012.09.147.

Brown J., Hendry C. and Harborne P. (2007), An emerging market in fuel cells? Residential combined heat and power in four countries. Energy Policy, 35(4), 2173-2186. DOI: 10.1016/j.enpol.2006.07.002

BUBW (2015), Nasslackieren. Spritzlackieren. Edited by Betrieblicher Umweltschutz Baden-Württemberg. Betrieblicher Umweltschutz Baden-Württemberg. Available online at http://www.bubw.de/?|vl=465, checked on 10/9/2015.

Buchert M., Jenseit W., Dittrich S. and Hacker F. (2011), Ressourceneffizienz und ressourcenpolitische Aspekte des Systems Elektromobilität. Öko-Institut e.V. Darmstadt, Germany. Available online at https://www.oeko.de/ oekodoc/1334/2011-449-de.pdf, checked on 12/1/2017.

CALLUX (2017), Callux, Praxistest Brennstoffzelle fürs Eigenheim. Hintergründe und Aktivitäten. Available online at https://www.now-gmbh.de/content/2-bundesfoerderungwasserstoff-und-brennstoffzelle/5-strom-und-waerme-mitbrennstoffzellen/1-callux/callux_p8_edel_15-11-26.pdf, checked on $11 / 27 / 2017$.

DLR (2004), Final report on technical data, costs and life cycle inventories of fuel cells. Deliverable $n^{\circ} 9.2$ - RS $1 a$. With assistance of IFEU POLITO. DLR. Available online at http://www.needs-project.org/2009/Deliverables/RS1a\%20 
D9.2\%20Final\%20report\%20on\%20fuel\%20cells.pdf, checked on $11 / 27 / 2017$.

Dodds P., Staffell I., Hawkes A., Li F., Grünewald P., McDowall W. and Ekins P. (2015), Hydrogen and fuel cell technologies for heating. A review. International Journal of Hydrogen Energy, 40(5), 2065-2083. DOI: 10.1016/j.ijhydene.2014.11.059.

Erdmann V. (2013), Mikro-Kraft-Wärme-Kopplungsanlagen, Status und Perspektiven. Verein Deutscher Ingenieure (VDI). Düsseldorf, Germany. Available online at https://www.vdi.de/uploads/media/StatusreportMKWK_2013.pdf, checked on 11/27/2017.

Fecarotti C., Andrews J. and Chen R. (2016), A Petri net approach for performance modelling of polymer electrolyte membrane fuel cell systems. International Journal of Hydrogen Energy, 41(28), 12242-12260. DOI: 10.1016/j.ijhydene.2016.05.138.

Fuel Cell Today (2017), The Fuel Cell Industry Review 2012. Edited by Johnson Matthey PLC. Available online at www.technology.matthey.com/pdf/273-274-pmr-oct12.pdf, checked on 11/27/2017.

Grot S. and Grot W. (2007), Platinum Recycling Technology Development. Excerpt from 2007 DOE Hydrogen Program Annual Progress Report. Ion Power, Inc. New Castle, USA. Available online at https://www.hydrogen.energy.gov/pdfs/ progress05/vii_e_1_grot.pdf, checked on 11/28/2017.

Hagelüken C. (2012), Recycling the Platinum Group Metals. A European Perspective. Platinum Metals Review, 56(1), 2935. DOI: 10.1595/147106712X611733.

Hagelüken C., Lee-Shin J., Carpentier A. and Heron C. (2016), The EU circular economy and its relevance to metal recycling. Recycling, 1(2), 242-253. DOI: 10.3390/recycling1020242.

HFP (2005), European Hydrogen and Fuel Cell Technology Platform. Deployment Strategy. Available online at http://www.fch.europa.eu/sites/default/files/documents/hf p_ds_report_aug2005.pdf, checked on 11/27/2017.

Jungbluth C. (2007), Kraft-Wärme-Kopplung mit Brennstoffzellen in Wohngebäuden im Zukünftigen Energiesystem. Jülich, Germany. Available online at https://www.deutsche-digitalebibliothek.de/binary/6YZTN5LJN33ASZ6TEQRU72RZSAKBRCZ Z/full/1.pdf, checked on 11/27/2017.

Knights S.D., Colbow K.M., St-Pierre J. and Wilkinson D.P. (2004), Aging mechanisms and lifetime of PEFC and DMFC. Journal of Power Sources, 127(1-2), 127-134. DOI: 10.1016/ j.jpowsour.2003.09.033.

Köhler J., Zuber R., Binder M., Baenisch V. and Lopez M. (2006), Process for recycling fuel cell components containging precious metals on 3/9/2006. App. no. PCT/EP2005/009359.

Krewitt W., Nitsch J., Fischedick M., Pehnt M. and Temming $\mathrm{H}$. (2006), Market perspectives of stationary fuel cells in a sustainable energy supply system-long-term scenarios for Germany. Energy Policy, 34(7), 793-803. DOI: 10.1016/j.enpol.2004.08.010.

Kromer M.A., Joseck F., Rhodes T., Guernsey M. and Marcinkoski J. (2009), Evaluation of a platinum leasing program for fuel cell vehicles. International Journal of Hydrogen Energy, 34(19), 8276-8288. DOI: 10.1016/j.ijhydene.2009.06.052.

Larminie J. and Dicks A. (2003), Fuel Cell Systems Explained, Second Edition, Hoboken, USA: Wiley.

Matathil A., Ganapathi K. and Ramachandran K. (2012), Reduction of scrap in an electronic assembly line using DMAIC approach. SASTECH Journal, 11(2). Available online at
http://www.sastechjournal.com/pdf/Journals/Sept2012/8.p df, checked on 11/30/2017.

Pehnt M. (2002), Fuel Cell Handbook, Volume 3 - Fuel Cell Technology and Applications. Life Cycle Assessment of Fuel Cell Systems: Wiley.

Saternus M., Fornalczyk A. and Cebulski J. (2014), Analysis of platinum content in used auto catalytic converter carriers and the possibility of its recovery. Archives of Metallurgy and Materials, 59(2). DOI: 10.2478/amm-2014-0092.

Shokri A., Nabhani F. and Bradley G. (2015), Reducing the scrap rate in an electronic manufacturing SME through Lean Six Sigma methodology. Available online at https://core.ac.uk/download/pdf/46520216.pdf, checked on 11/30/2017.

Simons A. and Bauer C. (2015), A life-cycle perspective on automotive fuel cells. Applied Energy, 157, 884-896. DOI: 10.1016/j.apenergy.2015.02.049.

Stahl H., Bauknecht D., Hermann A., Jenseit W. and Köhler A. (2016), Ableitung von Recycling- und Umweltanforderungen und Strategien zur Vermeidung von Versorgungsrisiken bei innovativen Energiespeichern. Edited by UBA. Umweltbundesamtes. Dessau-Roßlau, Germany. Available online at https://www.umweltbundesamt.de/sites/default/ files/medien/378/publikationen/texte_07_2016_ableitung_v on_recycling-und_umweltanforderungen.pdf, checked on $11 / 27 / 2017$.

Thijssen J. (2011), Solid Oxide Fuel Cells and Critical Materials. A Review of Implications. National Energy Technology Laboratory,. Redmon, USA.

Töpler J. and Lehmann J. (2014), Wasserstoff und Brennstofzellen. Technologien und Marktperspektiven. Berlin, Germany: Springer.

UMICORE (2005), Materials Flow of Platinum Group Metals, Umicore, London, UK

UNEP (2009), Critical Metals for Future Sustainable Technologies and their Recycling Potentials. United Nations Environment Programme \& United Nations University,. Darmstadt, Germany. Available online at http://www.unep.fr/ shared/publications/pdf/DTIx1202xPA-

Critical\%20Metals\%20and\%20their\%20Recycling\%20Potenti al.pdf, checked on 11/28/2017.

Wegner R. (2012), Rückgewinnung und Wiedereinsatz von Edelmetallen aus Brennstoffzellen. Teilprojekt: Mechanische Stack-Aufbereitung, Anwendungstest. ReMetall Drochow $\mathrm{GmbH}$. Drochow, Germanz. Available online at http://www.cleaner-production.de/fileadmin/assets/ 033R044A_-_Abschlussbericht.pdf, checked on 12/4/2017.

WGCRM (2014), Report on Critical Raw Materials for the EU. Report of the Ad hoc Working Group on defining critical raw materials. European Comission. Available online at http://www.catalysiscluster.eu/wp/wpcontent/uploads/2015/05/2014_Critical-raw-materials-forthe-EU-2014.pdf, checked on 11/27/2017.

Wittstock R., Pehlken A. and Wark M. (2016), Challenges in Automotive Fuel Cells Recycling. Recycling, 1(3), 344-364. DOI: $10.3390 /$ recycling1030343.

Zepf V. and Simmons J. (2014), Materials Critical to the Energy Industry - An Introduction. With assistance of University of Augsburg BP. Second Edition. London, United Kingdom: BP p.l.c. Available online at www.bp.com/energysustainabilitych allenge, checked on 11/27/2017. 